\title{
LEGISLATION
}

\section{Introducing a New Diminished Responsibility Defence for England and Wales}

\author{
Louise Kennefick*
}

A divisive law from the outset, the diminished responsibility defence has continued to arouse criticism since its inception over fifity years ago under section 2 of the Homicide Act 1957. Increasing pressure from academics, practitioners, and mental health professionals, among others, to restructure the law has resulted in a reformulation of the wording of section 2 under the unassuming auspices of section 52 of the Coroners and Justice Act 2009. This paper examines the new definition of diminished responsibility on two levels: the broader context and structural significance of the Act and section 52's place within it; and, the technical detail of the section itself. In so doing, consideration is given as to whether the new law appeases the critics of the old, in addition to whether the Government has succeeded in bringing to bear its objectives of clarity, fairness and effectiveness.

\section{INTRODUCTION}

The legislative definition of diminished responsibility has been an easy target for any critic ${ }^{1}$ since its inception under section 2 of the Homicide Act 1957.2 Calls for its reform have resonated for over half a century, with alternative drafts materialising from a miscellany of sources, most notably, the Butler Report, ${ }^{3}$ the Criminal Law Revision Committee, ${ }^{4}$ the Law Commission ${ }^{5}$ and several

\footnotetext{
*PhD candidate and Government of Ireland Scholar, University College Cork. The research for this paper is generously funded by the Irish Research Council for the Humanities and Social Sciences. I am grateful to Professor Caroline Fennell, to Dr Darius Whelan, and to the anonymous reviewer for their comments on an earlier draft of this paper.

1 P. R. Glazebrook, 'Dealing with Mentally Disordered Offenders' (1976) 35 Cambridge Law Journal 9, 12.

2 For example, Sparks opines that: ‘ . . it seems clear that, on balance, the practical effects of section 2 to date have been unsatisfactory in certain respects; that these ill effects would have been avoided if the law had not been passed in its present form; and that there is no way of insuring that they will be avoided in future, so long as the law remains as it now is,' R. Sparks, 'Diminished Responsibility in Theory and Practice' (1964) 27 MLR 9, 24. Griew is less sympathetic in his description of section 2, which he calls 'elliptical almost to the point of nonsense', E. Griew, 'Reducing Murder to Manslaughter: Whose Job?' (1986) 12 J Med E 18, 19. For Lady Wootton, the definition is essentially illogical, B. Wootton, 'Diminished Responsibility: A Layman's View' (1960) 76 LQR 224, 236.

3 Committee on Mentally Abnormal Offenders, Report Cm 6244 (1975).

4 Criminal Law Revision Committee: Offences Against the Person, Fourteenth Report Cm 7844 (1980) at [93].

5 Partial Defences to Murder, Law Commission Report No 290 (2004) and Murder, Manslaughter and Infanticide, Law Commission Report No 304 (2006).
} 
academic commentators. ${ }^{6}$ Discourse came to a head in November 2009, when the partial defence became the most recent subject of what has been described as the Government's 'protracted" review of the law of murder.

As a result, the definition of diminished responsibility in England and Wales has been reformed significantly under the unlikely framework of the Coroners and Justice Act 2009. ${ }^{8}$ Although largely concerned with reform of coroner law, section 52 of the Act introduces replacement wording for diminished responsibility which, as we will see, differs considerably from the old law. The purpose of the Act, in the particular context of its application to the criminal law, is to update the latter in order to 'improve its clarity, fairness and effectiveness.' ${ }^{9}$ It is accepted that such values are largely employed as guiding principles, with greater importance naturally being attached to responding to long held criticisms in the area. That said, consideration as to whether the Government has adequately applied such values in its reshaping of the law, too, plays its part in an examination of the new definition of diminished responsibility.

Clarity, fairness and effectiveness are worthy ideals in the criminal law. As Ashworth points out, principles based on clarity are essential to the rule of law, insofar as they conduce to predictability, consistency and accountability in decision-making. ${ }^{10}$ Of course, such order is only of benefit if it aligns with the inherent legal concept of fairness, particularly in terms of procedure, labelling and disposal. And neither clarity nor fairness is of any real use if the criminal law is not effective, or capable of realising the objective it was implemented for.

To determine whether the Government's approach under section 52 adheres to the values so propounded, in addition to whether the critics have been answered, this paper examines the potential impact of the new law in two respects. In the first instance, consideration is afforded to the context in which the criminal justice element of the Act has emerged, in addition to the structure it has taken. Secondly, an examination of the substantive content of section 52 of the Act will focus on how the new law has replied to criticism of the old wording of the defence.

\section{CONTEXT AND STRUCTURE OF CRIMINAL JUSTICE REFORM UNDER THE ACT}

Changes to the law of diminished responsibility stem from a request by the Home Secretary in 2003 for the Law Commission to consider and report on the

6 For example, R. D. Mackay, 'Diminished Responsibility and Mentally Disordered Killers' in A. Ashworth and B. Mitchell (eds), Rethinking English Homicide Law (Oxford: OUP, 2000) 55.

7 Editorial,'Adjusting the Boundaries of Murder: Partial Defences and Complicity' [2008] Crim L R 829, 829.

8 The Act received Royal Assent on 12 November 2009. The Commencement Date for s 52 was 4 October 2010 (Commencement No.4). For a detailed review of the wording of the definition, see R. D. Mackay, 'The Coroners and Justice Act 2009 - Partial Defences to Murder (2) The New Diminished Responsibility Plea’ [2010] Crim L R 290.

9 Coroners and Justice Act 2009, Explanatory Notes at [14]. This echoes the Law Commission's emphasis on bringing 'order, fairness and clarity to the law of homicide', Law Commission Report (2006), n 5 above at [2.4].

10 A. Ashworth,'Principles, Pragmatism and the Law Commission's Recommendations on Homicide Law Reform’ [2007] Crim L R 333, 344. 
law and practice of the partial defences to murder, ${ }^{11}$ in the particular context of domestic violence. This resulted in the Law Commission's report on Partial Defences to Murder in 2004. ${ }^{12}$ The crux of the Commission's recommendation in relation to diminished responsibility was that, for as long as the law of murder remains as it is, with conviction carrying a mandatory sentence of life imprisonment, the definition under section 2(1) should remain unchanged. ${ }^{13}$ The Commission opined that the definition did not cause injustice and, as such, it would be more appropriate to postpone reform of diminished responsibility until such time as the Government tasks it with conducting a full review of the entire law relating to murder, at which time partial defences could be considered from first principles. $^{14}$

In a promising development the Government did just that, with the result that the Law Commission published a report on Murder, Manslanghter and Infanticide in 2006. ${ }^{15}$ The Report recommended that the Homicide Act 1957 should be replaced by a new Homicide Act for England and Wales which would once and for all provide coherent and comprehensive definitions of homicide offences and partial defences. ${ }^{16}$ To restructure the offences of homicide, the Law Commission recommended a 'ladder' principle involving a hierarchy of graduated offences existing under the umbrella of homicide, which would reflect the offences' degree of seriousness. ${ }^{17}$ The offences would therefore be split into two degrees of murder, with the mandatory penalty restricted to first degree murder. ${ }^{18}$ The Law Commission envisaged that diminished responsibility (together with gross provocation or fear of serious violence and participation in a suicide pact) would be retained as a partial defence, with a successful plea having the effect of reducing first degree murder to second degree murder. ${ }^{19}$ In terms of the substantive law of diminished responsibility, it recommended that the definition be modernised, so that it would be both clearer and better able to accommodate developments in expert diagnostic practice. ${ }^{20}$

11 Homicide Act 1957, s 2 (Diminished Responsibility) and s 3 (Provocation).

12 Law Commission Report (2004), n 5 above. For discussion see Editorial,'Partial Defences to Murder' [2004] Crim L R 1.

13 Law Commission Report (2004), n 5 above at [1.16].

14 It is only in the context of a full review that the Commission proposed a definition of diminished responsibility based on its prior consultation process. The Commission's proposal received much support from academic commentators. For example, see Editorial, , 'Adjusting the Boundaries of Murder: Partial Defences and Complicity' [2008] 11 Crim L R 829.

15 Law Commission Report (2006), n 5 above. For commentary on the Law Commission's preceding Consultation Paper, A New Homicide Act for England and Wales?, Consultation Paper No 177 (2005), see: Editorial,'Reviewing the Law of Homicide' [2006] Crim L R 187; W. Wilson,'The Structure of Criminal Homicide' [2006] Crim L R 471; A. Norrie, 'Between Orthodox Subjectivism and Moral Contextualism: Intention and the Consultation Paper' [2006] Crim L R 486; O Quick and C Wells, 'Getting Tough with Defences' [2006] Crim L R 514; V. Tadros, 'The Homicide Ladder' (2006) 69 MLR 601.

16 Law Commission Report (2006), n 5 above at [1.63]. For further discussion see, Ashworth, above $\mathrm{n}$ 10, R. Taylor, 'The Nature of "Partial Defences" and the Coherence of (Second Degree) Murder' [2007] Crim L R 345.

17 Law Commission Report (2006), n 5 above at [1.64].

18 Law Commission Report (2006), n 5 above at [1.67].

19 Law Commission Report (2006), n 5 above at [5.83].

20 Law Commission Report (2006), n 5 above at [5.107]. 
Yet, the Law Commission's proposal went largely unheeded by the Government in its subsequent consultation paper. ${ }^{21}$ Here, the Government accepted the basic premise that the partial defence of diminished responsibility should be retained but reformed, and broadly agreed with the Commission's recommendations on how this should be done. However, it did so in the context of the existing structure of murder law, despite the fact that the Law Commission's recommendations were predicated on their proposed new homicide offence structure. ${ }^{22}$ Indeed, the paper states that 'the wider recommendations in the Law Commission's report may be considered at a later stage of the review' (emphasis added). However, the fact that the Government has engaged in solely amending the partial defences, suggests that it will be some time before the offence structure is reformed:.. . it would make no sense at all to adjust the outer boundaries of murder at this stage, as the [Government consultation paper] proposes to do, if the whole map might be redrawn later. It is a sad fate for a good proposal. ${ }^{23}$

The Government's departure from the Law Commission's proposals has been defended on the basis that the latter were 'somewhat radical' and 'did not command total agreement between all stakeholders and users of the system. ${ }^{24}$ As a result, the Government was apparently unable to come to a consensus that led it to believe that it should proceed with the full panoply of restructuring the offence as well as splitting it up' at that time. ${ }^{25}$ Although indication was given that there will be a second stage to the Government's considerations about whether to go forward with some of the other proposals in the Law Commission's report, as it stands, the position is not ideal.

Turning to the structure of the Act, unsurprisingly, much of it is dedicated to the reform of coroner law and procedure. A more fragmentary approach is given to the 'justice' element of the Act. In addition to reforming the law of diminished responsibility, the Act also amends the law of provocation and the law of assisted

21 Murder, Manslaughter and Infanticide: Proposals for Reform of the Law, Ministry of Justice Consultation Paper CP19/08 (2008). For discussion see Editorial, ,'Adjusting the Boundaries of Murder: Partial Defences and Complicity' [2008] 11 Crim L R 829.

22 Ministry of Justice Consultation Paper (2008), ibid. at [9].

23 Editorial, 'Adjusting the Boundaries of Murder: Partial Defences and Complicity' [2008] 11 Crim L R 829, 829. David Howarth, (then MP), echoes this sentiment when referring to the Coroners and Justice Bill 2009: 'Unfortunately, the Government have [sic] changed the reformed defences from the Law Commission's work and have put the narrower versions of the defences into the Bill without having reformed the law of murder itself, and it is arguable that that makes no sense at all. The Government need to come back with a complete reform.' Coroners and Justice Bill, HC Public Bill Committee col 4093 March 2009.

24 Maria Eagle (then Parliamentary Under-Secretary of State for Justice), Coroners and Justice Bill, HC Public Bill Committee col 4133 March 2009.

25 ibid. The Government's official response to its failure to implement the full Law Commission proposals reads as follows:

The Law Commission's recommendations for this important and sensitive area of law are ambitious and wide-ranging; it is critical that we get this right and so we have proceeded on a staged basis. We will be looking at the Commission's other recommendations, in particular those for a new structure for homicide and complicity to murder, in due course, in the light of the effect of any changes arising from this stage of the work.

Murder, Manslaughter and Infanticide: Proposals for Reform of the Law, Summary of Responses and Government Position, Ministry of Justice Responses to Consultation CP(R) 19/08 (2009) at [120]. 
suicide, ${ }^{26}$ introduces new measures in relation to child pornography offences, data sharing, and legal aid, and much more. ${ }^{27}$ Whether it is the most appropriate framework for dealing with important changes to the law of homicide, then, is questionable.

Homicide law in England and Wales has been described by the Law Commission as 'misleading, out-of-date, unfit for purpose, or all of these. ${ }^{28}$ To address this criticism by dealing with one element of the law only, in an Act concerned with a dense compilation of other, unrelated matters, does not inspire clarity in law. The means by which the law of homicide has been amended in this Act is arguably unfit for purpose, in that it fails to address systematically the entirety of the law of homicide.

It is suggested that instead of appending important reforms to murder law to what has been described as a 'gargantuan ${ }^{29}$ Act dealing with all manner of criminal, procedural and administrative law, it would be more appropriate to construct a separate Act which would address the necessary reforms to the law of homicide, notwithstanding the delay that this would inevitably bring. Indeed, the fact that this has not occurred suggests to one commentator that the substantive law of murder will not be reformed any time soon, if at all. ${ }^{30}$

A related point concerns the lack of adequate consideration having been afforded to the relationship between diminished responsibility and insanity, given that both are concerned with issues of mental disorder, together with the fact that the law relating to the latter is currently under review by the Law Commission. ${ }^{31}$ A more appropriate process of reform would see a re-evaluation of the criminal law at all the points at which it meets issues relating to mental disorder, in order to ensure consistency and fairness in processes dealing with offenders with mental disorders. An example of such an approach in practice can be seen in Ireland, where the law relating to unfitness to plead, insanity and diminished responsibility was the subject of a synchronised reformulation under the Criminal Law (Insanity) Act 2006. ${ }^{32}$

It is a moot point as to whether the guiding principles set out by the Government apply to the scaffolding of the law. If one accepts that they do, the question must be asked as to whether they have been adequately taken into account in this instance. A piecemeal approach to reforming the law of homicide by merely

26 Coroners and Justice Act 2009, ss 52-56.

27 See Editorial, 'The Coroners and Justice Act 2009' [2010] Crim L R 1,1-2, which summarises the subject matter of each of the seven parts of the Act.

28 Law Commission Report (2006), n 5 above at [1.70].

29 J. Miles, 'The Coroners and Justice Act 2009: a “Dog's Breakfast” of Homicide Reform' (2009) 10 Arch News 6, 6.

30 Editorial,'Adjusting the Boundaries of Murder: Partial Defences and Complicity' [2008] 11 Crim L R 829, 829.

31 Tenth Programme of Law Reform, Law Commission No 311 (2008-2011), Project 7: Unfitness to Plead and the Insanity Defence. The Law Commission opines that '... there is a need to reconsider the relationship between ... diminished responsibility and insanity' at [1.20].

32 For further discussion of the Irish experience, see D. Whelan, 'The Criminal Law (Insanity) Act 2006' in T. J. McIntyre, K. Spencer and D. Whelan, Criminal Legislation Annotated $2006-2007$ (Dublin: Thomson Round Hall, 2008); D. Whelan, Mental Health Law and Practice (Dublin: Round Hall, 2009), ch 16; G. Coonan and B. Foley, The Judge's Charge in Criminal Trials (Dublin: Round Hall, 2008), ch 16. 
addressing the partial defences in an Act dedicated to a multiplicity of matters is ineffective and unclear, in the sense that it fails to take into account the broader contextual recommendations of the Law Commission, in addition to how the criminal law relates comprehensively to offenders with mental disorders. Albeit a step in the right direction, it remains to be seen whether the reformulation of the defences in isolation does more harm than good; particularly in light of the fact that, notwithstanding its ambiguous and archaic nature, the original definition of diminished responsibility has worked well in practice. ${ }^{33}$

\section{SUBSTANTIVE CONTENT OF SECTION 52 OF THE ACT}

Section 2(1) of the Homicide Act 1957 provided that:

[w] here a person kills or is a party to the killing of another, he shall not be convicted of murder if he was suffering from such abnormality of mind (whether arising from a condition of arrested or retarded development of mind or any inherent causes or induced by disease or injury) as substantially impaired his mental responsibility for his acts or omissions in doing or being a party to the killing.

Under the original definition, then, there existed two basic requirements in order to bring a successful plea of diminished responsibility. In the first instance, the accused must have been suffering from an 'abnormality of mind', and secondly, that abnormality must have 'substantially impaired his mental responsibility for the killing' The defence has been interpreted by the courts to cover a wide range of mental conditions, ${ }^{34}$ including psychopathy, volitional insanity and alcoholism. ${ }^{35}$ The scope of the defence also went so far as to include the mercy-killer. ${ }^{36}$

Although naturally overlapping principles, the next section addresses the various criticisms pertaining to diminished responsibility under the headings of clarity and fairness. Effectiveness is also considered but to a lesser extent. The discussion is not restricted to these headings, but their use serves the purpose of keeping in mind the Government's goals when considering the criticisms of the old law.

\section{Issues pertaining to clarity}

The primary grievance with the old definition is its lack of clarity in relation to two aspects of its phraseology. Firstly, the term 'abnormality of mind' (and the bracketed aetiological causes) which has been deemed obscure and inadequate in

33 O. Quick and C. Wells, 'Getting Tough with Defences' [2006] Crim L R 514, 520.

34 R. D. Mackay, 'The abnormality of mind factor in diminished responsibility' [1999] Crim L R 117, 117.

35 For further discussion on the accession and practical application of diminished responsibility in England and Wales under the original definition, see E. E. Tennant, The Future of the Diminished Responsibility Defence to Murder (Chichester: Barry Rose, 2001).

36 For discussion in this context see, G. Williams, Textbook of Criminal Law (London: Stevens, $2^{\text {nd }}$ ed, 1983) 693; E. Griew, ‘The Future of Diminished Responsibility’ [1988] Crim L R 75, 79-80; A. Ashworth, Principles of Criminal Law (Oxford: OUP, 2009). 
a medical diagnostic sense; and secondly, substantial impairment of mental responsibility' which also throws up definitional issues. Section 52 of the Coroners and Justice Act responds to these criticisms by introducing a revised partial defence of diminished responsibility based on the concept of a recognised medical condition' with the objective of spelling out more clearly what aspects of a defendant's functioning must be affected in order for the partial defence to succeed. ${ }^{37}$

Section 52 replaces the wording of section 2(1) of the Homicide Act 1957 with the following, which if pleaded successfully, has the effect of reducing a conviction of murder to one of manslaughter:

(1) A person ('D') who kills or is a party to the killing of another is not to be convict ed of murder if $\mathrm{D}$ was suffering from an abnormality of mental functioning which -

(a) arose from a recognised medical condition,

(b) substantially impaired D's ability to do one or more of the things mentioned in subsection $(1 \mathrm{~A})$, and

(c) provides an explanation for D's acts and omissions in doing or being a party to the killing.

(1A) Those things are -

(a) to understand the nature of D's conduct;

(b) to form a rational judgment;

(c) to exercise self-control.

(1B) For the purposes of subsection (1)(c), an abnormality of mental functioning provides an explanation for D's conduct if it causes, or is a significant contributory factor in causing, D to carry out that conduct.

Although responding to the criticisms regarding a lack of clarity, as Mackay points out, the new wording introduces its own complications, for example, the addition of a causation requirement, to the effect that the abnormality should cause or be a significant contributory factor in causing the defendant to kill. ${ }^{38}$ The new phraseology will now be considered in further detail.

\section{'Abnormality of Mental Functioning'Arising from a 'Recognised Medical Condition'}

The original phrase abnormality of mind' together with the bracketed aetiological causes which follow it, ${ }^{39}$ are not psychiatric terms, and so their meaning has had to be developed by the courts from case to case. It is arguable, therefore, that the result of this definition has been a lack of consistency in the law, a criticism which the Government has sought to redress with the more meticulous wording of section 52. Yet, in practice the bracketed causes, though outmoded, infrequently used

37 Ministry of Justice Consultation Paper (2008), n 21 above, 2.

38 R. D. Mackay, 'The Coroners and Justice Act 2009 - Partial Defences to Murder (2) The New Diminished Responsibility Plea’ [2010] Crim L R 290, 293.

39 ' $[\mathrm{A}]$ condition of arrested or retarded development of mind or any inherent causes or induced by disease or injury'. 
and without an agreed psychiatric meaning, have facilitated flexible interpretation. ${ }^{40}$ However, although the Law Commission acknowledged that the wording was not causing an injustice, it expressed concern that diagnostic practice in diminished responsibility cases has long since developed beyond identification of the narrow range of causes of an abnormality of mind, a point with which the Government agreed. ${ }^{41}$

Under section 52, the somewhat nebulous 'abnormality of mind' has been replaced by the phrase 'abnormality of mental functioning'. (Curiously, this comes at a time when the 'abnormality of mind' phrase has been enshrined into Scottish legislation). ${ }^{42}$ The bracketed words have been removed and replaced with the term 'recognised medical condition'. The effect is that the law is no longer constrained by the fixed set of causes from which an abnormality of mental functioning must stem. Instead, the issue is whether the abnormality was brought about by a 'recognised medical condition'. The Royal College of Psychiatrists has supported this change:

The presence of such a restriction ... would ensure that any such defence was grounded in valid medical diagnosis. It would also encourage reference within expert evidence to diagnosis in terms of one or two of the accepted internationally classificatory systems of mental conditions (WHO ICD10 and AMA DSM) without explicitly writing those systems into the legislation ... Such an approach would also avoid individual doctors offering idiosyncratic 'diagnoses' as the basis for a plea of diminished responsibility. ${ }^{43}$

Thus, in practice, it is likely that psychiatric classificatory systems will play a more central role in establishing the existence of a recognised medical condition resulting in an abnormality of mental functioning. Of course, most diagnoses by experts under the original definition would have had some recognised medical basis. The new wording, however, makes this requirement essential, so in that respect, it clarifies the law. But this change in definition may have more far-reaching consequences than initially anticipated. Accepting that it has not yet been

40 R. D. Mackay, 'The Abnormality of Mind Factor in Diminished Responsibility’ [1999] Crim L R 117, 117. Elsewhere, Mackay discusses how court report writers have frequently failed to consider the bracketed causes, with the result that the majority of reports did not discuss the aetiological causes of the defendant's abnormality of mind, see Law Commission Report (2004), n 5 above, Appendix B, Table 18, 156.

41 Law Commission Report (2006), n 5 above at [5.111].

42 Criminal Justice and Licensing (Scotland) Act 2010, s 168, provides that the following definition be inserted into the Criminal Procedure (Scotland) Act 1995 at s 51B:

(1) A person who would otherwise be convicted of murder is instead to be convicted of culpable homicide on grounds of diminished responsibility if the person's ability to determine or control conduct for which the person would otherwise be convicted of murder was, at the time of the conduct, substantially impaired by reason of abnormality of mind.(2) For the avoidance of doubt, the reference in subsection (1) to abnormality of mind includes mental disorder.

This reformulation of the law follows from the Scottish Law Commission's report on Insanity and Diminished Responsibility, Scottish Law Commission Report No 195 (2004), which recommended that the decision in Galbraith v HM Advocate $2002 \mathrm{JC} 1$ be implemented as a statutory definition in the form of a plea in mitigation in cases of murder. See further, J. Chalmers and F. Leverick, Criminal Defences and Pleas in Bar of Trial (Edinburgh: W Green, 2006).

43 Law Commission Report (2006), n 5 above at [5.114]. 
interpreted by the courts, the term 'recognised medical condition', as it stands, has the effect of narrowing the defence of diminished responsibility by excluding those disorders which may no longer or may not yet be accepted internationally as 'medical conditions'.

The original definition had progressed to the point where it was interpreted by the courts to show leniency to a 'highly stressed killer', in the sense that a defendant could receive a manslaughter verdict if the particular form of stress in question was pathologised as diminished responsibility. ${ }^{44}$ This trend is also reflected in prominent domestic violence cases of the early 1990s featuring the controversial 'Battered Woman's Syndrome'. ${ }^{45}$ Such forms of interpretation have been described as a 'benign conspiracy' ${ }^{46}$ which stretched the notion of 'abnormality of mind', to enable a verdict to meet the perceived justice of the case. ${ }^{47}$ The restriction of the law to internationally medically recognised and documented conditions brings the possibility of a defendant (for example a 'mercy-killer') being convicted of murder and given a mandatory life sentence, despite his or her responsibility for the killing being far removed from 'the gangland executioner and the serial killer who likes to torture his victims first'. ${ }^{48}$

So although the introduction of 'recognised medical condition' may promote the principle of clarity, conversely, it draws into question the fairness of the situation for the offender pleading diminished responsibility. Should both the court and the expert utilise a strict interpretation of the phrase, the likelihood of a 'mercy killer' being brandished a 'murderer' and sentenced to life imprisonment increases. Thus, the new law of diminished responsibility has a potentially damaging impact on a particular group of offenders who could have availed of the partial defence under the original definition.

44 Editorial, 'Adjusting the Boundaries of Murder: Partial Defences and Complicity' [2008] 11 Crim L R 829, 830.

45 See, Rv Ahluwalia [1992] 4 All ER 889 and RvThornton [1992] 1 All ER 306. Defences of provocation failed in both cases; however diminished responsibility defences were successful at retrial. What is evident is the medicalisation of the experience of these women rather than an acknowledgement of the broader political, social and economic contexts of violence in a domestic setting. For an interesting discussion, see the Victorian Law Reform Commission's report on Defences to Homicide: Final Report, Victorian Law Reform Commission Report (2004) and M. Donnelly, 'Battered Women who Kill and the Criminal Law Defences' (1993) Irish Criminal Law Journal 161.

46 Law Commission Report (2004), n 5 above at [2.34].

47 See the written evidence of the British Humanist Association (BHA), 'Coroners and Justice Bill: Memorandum', Ev 37, in Human Rights Joint Committee, Legislative Scrutiny: Coroners and Justice Bill, Eighth Report HL Paper 57, HC 362 (2009).The BHA, although not endorsing the 'benign conspiracy' or 'mercy killing', makes the point that 'mercy killings' are taking place, and it is necessary that the law addresses these cases appropriately. It expresses concern that the revised definition of diminished responsibility will make the situation worse for genuine 'mercy killers' and seriously impact upon their human rights. See also, A. Ashworth, Principles of Criminal Law (Oxford: OUP, $5^{\text {th }}$ ed, 2006) at 283; B. Mitchell, 'Public Perceptions of Homicide and Criminal Justice' (1998) 38 B J Crim 453, 460.; S. Dell, Murder into Manslaughter (Oxford: OUP, 1984) 35-6, Dell identifies some 10 cases which have a mercy killing element within the research period. Mackay's more recent study of 157 cases in which diminished responsibility was raised, suggests that six were probably cases of mercy killing, see R. D. Mackay, 'The Diminished Responsibility Plea in Operation - An Empirical Study', in Law Commission Report (2004), n 5 above, Appendix B.

48 Editorial, 'Adjusting the Boundaries of Murder: Partial Defences and Complicity' [2008] 11 Crim L R 829, 830 . 
Time will tell how the system responds to this particular circumstance in practice. It may well be the case that the courts will likewise stretch their interpretation of the term 'recognised medical condition', or the experts their diagnoses, in order to enable the 'benign conspiracy' to continue, albeit in a slightly different guise. ${ }^{49}$ Should this be the case, whether or not the clarity of the law relating to diminished responsibility has been improved by section 52 would be brought into question.

\section{Determining Mental Responsibility}

Professor Ashworth speaks for the majority when he opines that the old wording of section 2(1) is clumsy when it refers to 'impairing mental responsibility'. ${ }^{50} \mathrm{He}$ maintains that the definition should, in fact, refer to the substantial impairment of the defendant's capacity, which, in turn, is reflected in his reduced culpability at sentencing in the form of a discounted conviction from murder to manslaughter. ${ }^{51}$ Section 52 seeks to address this criticism by clarifying what impact on capacity the effects of an abnormality of mental functioning must have, if the abnormality is to be the basis for a successful plea. ${ }^{52}$ It does so by seeking to expand the meaning of what is termed 'mental responsibility' under the original definition, without incorporating that phraseology into the new law. Section 52 sets out the following capacities, the absence of one or more of which, go to the substantial impairment of the defendant's mental functioning: to understand the nature of his or her conduct, to form a rational judgment, and to exercise selfcontrol.

Whilst the Law Commission claims that under this recommendation, there will remain an important theoretical distinction between the insanity plea and the plea of diminished responsibility ${ }^{53}$ this definition is, in part, very similar to the insanity defence ${ }^{54}$ In terms of cognition, the same test is applied in relation to

49 For example, see Quick and Wells who surmise that: 'In practice, the definition of the defence is in the hands of expert witnesses, whose sympathies understandably rest with defendants struggling with various mental states and the spectre of the mandatory life sentence for murder', Quick and Wells, above n 33, 520 .

50 A. Ashworth, Principles of Criminal Law (Oxford: OUP, $5^{\text {th }}$ ed, 2006) 279.

51 ibid 279. See also Sparks' comments in respect of 'mental responsibility':

... the section is quite intelligible if (but, it is submitted, only if) 'mental responsibility' is taken to refer to the mental capacity which is morally a necessary condition of legal responsibility (in the sense of liability to punishment). On this interpretation the section would substitute a verdict of manslaughter for one of murder, thus providing for mitigation of punishment, if the accused's mental capacity to control his conduct so as to conform to the law was 'substantially impaired' by mental disorder. This is, of course, the substance of the Scottish doctrine on which the section is based ... on this interpretation, it is submitted that it cannot, in these or any other terms, be reconciled with our usual moral and legal principles: since according to these it is never appropriate to base mere mitigation of punishment on mental incapacity.

R. Sparks, 'Diminished Responsibility in Theory and Practice' (1964) 27 MLR 9, 26.

52 Law Commission Report (2006), n 5 above at [5.121].

53 ibid at [5.114].

54 The insanity defence in England and Wales, although currently under review by the Law Commission, remains governed by the M'Naghten Rules, as a result of controversy following the case of Daniel M'Naghten (1843) $10 \mathrm{Cl}$ and Fin 200. According to the M'Naghten Rules it must be established that cognitive incapacity, 'defect of reason' was caused by a 'disease of the mind', such that the defendant did not to know the nature and quality of the act he was doing; or, if he did know it, that 
insanity and diminished responsibility; it is just the degree of the understanding that is judged. There exists, however, an additional volitional element to the diminished responsibility definition, which was elucidated in the decision in $R v$ Byrne. ${ }^{55}$ At the appellate stage of this case, Lord Parker CJ held that the term 'mental responsibility' is:

... wide enough to cover the mind's activities in all its aspects, not only the perception of physical acts and matters, and the ability to form a rational judgement as to whether an act is right or wrong, but also the ability to exercise will-power to control his physical acts in accordance with that rational judgment. ${ }^{56}$

Section 52 incorporates the Byrne criteria into the legislative definition of the law, which is a sensible elucidation, and certainly a clarification of what is required by the notion of 'mental responsibility'. The primary issue with the Byrne criteria which section 52 fails to clarify, however, is the 'irresistible impulse' element, in that the difficulties and uncertainties which deterred judges from allowing the irresistible impulse defence under the M'Naghten Rules in the first place, still remain. ${ }^{57}$ As Lord Parker CJ opined: "[T]he step between "he did not resist his impulse" and "he could not resist his impulse" is ... one which is incapable of scientific proof . . . there is no scientific measurement of the degree of difficulty which an abnormal person finds in controlling his impulses. ${ }^{58}$

The section also fails to address the ambiguity that has surrounded the meaning of the term 'substantially impaired' under the original definition, a phrase which has been reincarnated under section 52 . There is evidence of judicial confusion as to what 'substantial' amounts to. It is clear that it requires more than 'trivial or minimal' impairment, ${ }^{59}$ or moderate impairment, ${ }^{60}$ but does not have to amount to borderline insanity. ${ }^{61}$ Although a pragmatic approach is taken in practice, it is surprising that the Government did not avail of the opportunity to delineate this phrase, given its objective of clarification.

he did not know he was doing what was wrong. This echoes Coroners and Justice Act 2009, s 52(1A) (a) and (b).

55 [1960] 2 QB 396. (Byrne was followed in Rose v R [1961] AC 496, PC, Rv Terry [1961] 2 QB 314; 45 Cr App R 180, CCA, Rv Gomez [1964] 48 Cr App R 310, CCA).

56 ibid 404, (Lord Parker CJ) emphasis added. The direction in Byrne was expressly approved in Terry, where the Court of Appeal held that the trial judge was required to provide the jury with a proper interpretation of the terms of section 2 as per Byrne, and that to merely read aloud the section was unacceptable.

57 D. Ormerod, Smith and Hogan Criminal Law (Oxford: OUP, $12^{\text {th }}$ ed, 2008). For an earlier discussion on irresistible impulse in the context of diminished responsibility, see J. E. Hall Williams, 'Irresistible Impulse and Diminished Responsibility' (1961) 24 MLR 164.

58 [1960] 3 All ER 1, 5 (Lord Parker CJ).

$59 R v$ Lloyd [1967] 1 QB 175 at 180, applied in $R \vee R$ [2010] EWCA Crim 194.

$60 R v$ Simcox [1964] Crim L R 402, considered in Rv R, ibid.

$61 R v$ Seers [1984] 79 Cr. App. Rep. 261 at 264. $R v$ Lloyd, n 59 above, 50 Cr App R 61 at 64, CCA, the court approved the following direction on the words 'substantially impaired' given by the trial judge:

Substantial does not mean total, that is to say the mental responsibility need not be totally impaired, so to speak, destroyed altogether. At the other end of the scale substantial does not mean trivial or minimal. It is something in between and Parliament has left it to you ... to say on the evidence: was the mental responsibility impaired, and, and if so, was it substantially impaired? 


\section{The Causation Requirement}

The Government chose to endorse the Law Commission's recommendation that the abnormality of mind element must be shown to be 'an explanation' for the defendant's conduct, thus ensuring that there is an appropriate connection between the abnormality of mental functioning and the killing. ${ }^{62}$ The original definition simply stated that the abnormality of mind must substantially impair the defendant's mental responsibility for his acts in doing or being a party to the killing. ${ }^{63}$ This particular amendment seeks to tackle the criticism that it has never been entirely clear whether, under the existing law, the abnormality of mind must, in some sense, 'cause' the defendant to kill. ${ }^{64}$

While certainly resolving the question as to whether causation is a requirement of a successful diminished responsibility defence, the definition fails to shed any light on the difficulties inherent in proving the link between the defendant's conduct and the abnormality of mental functioning. Furthermore, even if the causal element could be proven, Wilson makes a point which brings into question its fairness. ${ }^{65} \mathrm{He}$ highlights the 'rigorous and precise' nature of the new law, particularly in the context of the causal requirement. ${ }^{66}$ Because of this, he maintains, it is a strange conclusion to draw that the diminished responsibility defendant may be held responsible for the killing, in the same way as a defendant with normal mental functioning who kills with the intention to do serious injury or with reckless indifference. ${ }^{67}$ The 'fairness' (or lack thereof) in this scenario clearly goes to the issue of labelling, which is dealt with in further detail below.

\section{Issues pertaining to fairness}

This section addresses more general criticisms of the law of diminished responsibility which, though not dealt with expressly in the new definition, are nonetheless relevant. Such criticisms come under the umbrella of fairness. Therefore, a detailed review of the concept itself stretches beyond the remit of this paper, ${ }^{68}$

62 Law Commission Report (2006), n 5 above at [5.124]. See also the statement of Maria Eagle: 'We do not believe that the partial defence should succeed where random coincidence has brought together the activity of the person and the recognised medical condition. HC Public Bill Committee, n 24 above, col 416.

63 Law Commission Report (2006), n 5 above at [5.122].

64 See Byrne [1960] 3 WLR 440, 443-444: 'The expression "mental responsibility for his acts" points to consideration of the extent to which the accused's mind is answerable for his physical acts, which must include a consideration of the extent of his ability to exercise will-power to control his physical acts'.

65 W. Wilson, 'The Structure of Criminal Homicide' [2006] Crim L R 471, 483. Although Wilson discusses the Law Commission's definition, the point remains applicable to section 52.

66 ibid.

67 ibid.

68 For theoretical discussions on fairness in the context of the criminal law see, for example, R. A. Duff, Answering for Crime: Responsibility and Liability in the Criminal Law, (Oxford: Hart Publishing, 2007); V. Tadros, 'Attribution, Ethics and Emotions in Criminal Responsibility' (2004) 67 MLR 322.; N. Walker, Punishment, Danger and Stigma: The Morality of Criminal Justice (Oxford: Blackwell, 1980); G. P. Fletcher, The Grammar of Criminal Law (Oxford: OUP, 2007); J. Gardner, 'The Gist of Excuses' (1998) 1 Buffalo Criminal Law Review 575. 
however, it is dealt with in brief under the headings of procedural fairness and fair labelling.

\section{Procedural Fairness}

This section utilises Gardner's meaning of procedural fairness, rather than procedural fairness in the strict sense of the relative ability of each side of the adversarial process to argue their case. Gardner looks for fairness in the process of the defendant's opportunity to provide 'structured explanatory dialogue' in a public setting. ${ }^{69}$ He identifies a 'basic responsibility' which is represented in the criminal process by the ability of an individual to explain their position rationally. ${ }^{70}$ Thus, for Gardner, 'this point is not a point relative to which the procedure is instrumental; rather the point is in the procedure. ${ }^{71}$

It follows that procedural fairness can be found in one's ability or opportunity to explain oneself to a jury in a trial setting. How does the plea of diminished responsibility fare, then, if we apply Gardner's approach to it in a practical sense? The reality is that the majority of diminished responsibility cases do not reach the trial stage, ${ }^{72}$ largely due to the prevalence and weight afforded to psychiatric reports. ${ }^{73}$ With the introduction of the requirement of a 'recognised medical condition', it is possible that the cases will become more mechanical in terms of deciding who does and does not qualify for a successful plea. However, procedurally, this could result in even more defendants who plead diminished responsibility being deprived of their rational explanation of self in public.

There is another line of argument which suggests that, as ideal as a trial by jury may seem, in more difficult cases, particularly involving expert evidence, the jury is simply unable to deal with the questions put before it. ${ }^{74}$ So rather than

69 J. Gardner,'The Mark of Responsibility’ (2003) 23 OJLS 157, 167.

70 ibid 166 and 171.

71 ibid 167.

72 R. D. Mackay, 'The Diminished Responsibility Plea in Operation - An Empirical Study' in Law Commission Report (2004), n 5 above, Appendix B. During the research period (1997-2001) there had been a total of 157 defendants where diminished responsibility was identified as a defence which was raised during the course of the trial process. There was no jury trial in $77.1 \%(n=121)$ of the cases. See also T. Hardie S. Elcock and R. D. Mackay, 'Are Psychiatrists affecting the Legal Process by answering Legal Questions?' (2008) 18 Criminal Behaviour and Mental Health 117, 126.:

The data strongly suggest that pleas are being accepted without a trial in the majority of cases, which reflects previous work ... It is possible that the cases that go to trial are the ones for which there is properly genuine doubt about the appropriateness of the plea, and that the court is correctly avoiding wasting resources with unnecessary and expensive hearings for those that do not go to trial.

73 As it stands, research indicates that psychiatrists frequently answer the legal question of diminished responsibility, see Hardie et al, ibid 128, where half (169) of the psychiatric reports analysed between 1997-2001 gave a clear opinion on diminished responsibility, a third (121) invited the court to draw a particular conclusion and 11 per cent (36) provided relevant evidence without answering the legal questions. When there was an opinion or an invitation to make a finding on the legal question, a trial was less likely. A trial was also less likely if the psychiatric reports agreed on what the verdict should be.

74 For example, Lady Wootton has gone so far as to describe the burden laid upon the jury in this regard as 'improper', and remarks that: 'they are required to answer questions which are not only 
usurping the role of the jury, ${ }^{75}$ the expert is assisting the jury in coming to a decision; bringing its own complications. It is impossible to get inside the mind of the individual at the time of the offence, even for psychiatrists, therefore juries are being asked to base their decision on opinion, which usually involves choosing between two differing views.

In Rv Cannings, ${ }^{76}$ Judge LJ goes so far as to warn that... if the outcome of the trial depends exclusively or almost exclusively on a serious disagreement between distinguished and reputable experts, it will often be unwise, and therefore unsafe, to proceed. ${ }^{77}$ This is largely due to the fact that as psychiatrists give opinion evidence, it is likely that one expert's opinion of the facts will differ from the other. ${ }^{78}$ However, place this argument in the hands of the jury, and further difficulties arise. Juries will be quite unfamiliar with the technical language used by forensic psychiatrists, and as Blom-Cooper and Morris point out, this can be bewildering, not least when it is presented for many hours, and over many days. ${ }^{79}$

It appears, therefore, that the question as to who decides what in terms of the mental condition and criminal responsibility of the accused remains unclear, despite the goal of clarification underpinning the new law. What is clear, however, is that the system in place, which sees psychiatrists testifying in relation to responsibility, and juries attempting to decipher complicated psychiatric terminology, results in ambiguity, inconsistency and thus arguably unfair treatment of the mentally disordered offender.

\section{Fair Labelling}

Turning to fairness in the broader context of labelling, the term is a complicated one, as is demonstrated by the writings of Chalmers and Leverick. ${ }^{80}$ They point to the fact that there is a strong argument (incidentally one that they do not agree with) that fair labelling does not apply to the defences at all. ${ }^{81}$ However, as a partial defence, diminished responsibility is in an unusual position as, if pleaded successfully, it has the unique effect of altering a charge of murder to one of manslaughter. Thus, there is a strong argument that the notion of fair labelling is applicable to diminished responsibility as a partial defence.

beyond the competence of experts, but are by their very nature unanswerable by anybody ...' Wootton, $\mathrm{n} 2$ above, 236.

75 For discussion on the 'ultimate issue' rule which has traditionally prevented the use of expert evidence in relation to a question that falls to be determined by the judge or jury, see B. McSherry, 'Expert Testimony and the Effects of Mental Impairment: Reviving the Ultimate Issue Rule' (2001) 24 International Journal of Law and Psychiatry 13.

76 [2004] 1 All ER 725.

77 ibid at [178].

78 Add to this the fact that psychiatric assessments can take place long after the event in question and are carried out by both the prosecution and defence psychiatrists at different times. See further S. Morse, 'Failed Explanations and Criminal Responsibility: Experts and the Unconscious' (1982) 68 University of Virginia Law Review 971, 1027, wherein Morse considers how the 'measuring tool changes from examiner to examiner'.

79 L. Blom-Cooper and T. Morris, With Malice Aforethought: A Study of the Crime and Punishment for Homicide (Oxford: Hart Publishing, 2004), 85-86.

80 J. Chalmers and F. Leverick, 'Fair Labelling in Criminal Law' (2008) 71 MLR. 217.

81 ibid 244-246. 
In any event, the concept of 'fair labelling' is freely used by the Law Commission in relation to diminished responsibility. Because the Commission would have seen diminished responsibility having the effect of reducing first degree murder to second degree murder, it largely focussed on the notion of fair labelling in the context of avoiding the word 'murder' for successful diminished responsibility defences. ${ }^{82}$ However, it failed to deem anything unfair about the label second degree murder in cases where the partial defence would apply. ${ }^{83}$

Time lapse and unconscious acquiescence has resulted in a dearth of consideration being given to the term 'diminished responsibility' itself, as a label. It is problematic in the sense that it is not a medical term. The title of section 52 retains the concept of 'persons suffering from diminished responsibility', failing to acknowledge that diminished responsibility is not in itself a condition which can be suffered from, but is a legal definition. This made more sense under the original definition where there was more flexibility in terms of permitting the plea in cases where a strict medical condition did not exist.

Surprisingly, the body of section 52 has removed the term 'responsibility' entirely from the definition of diminished responsibility, no doubt with the intention of taking away those difficult legal and moral arguments which the word begets. In terms of fairness then, expanding on Gardner's point discussed above, it is unclear whether diminished responsibility refers to 'basic responsibility', ${ }^{84}$ or alternatively 'consequential responsibility', that is, 'being held responsible for what has gone amiss ... I am consequentially responsible if some or all of the unwelcome moral or legal consequences of some wrong or mistake (whether mine or someone else's) are mine to bear' ${ }^{85}$ Gardner assumes that rational defendants wish to avoid such responsibility ideally by justifying their actions, and failing that by means of excuse. ${ }^{86}$ This has a significant outcome for the defendant, as exemplified by Gardner in the context of the battered woman. He maintains that such defendants want to avoid consequential responsibility, but not at the cost of denying, or casting doubt on, their basic responsibility, which they wish to assert. $^{87}$ Thus, is the responsibility of the diminished responsibility defendant

82 Law Commission Report (2006), n 5 above at [2.147]. Noteworthy is the fact that the Government's Consultation Paper on the same matter refers to the concept of fair labelling once only, in the particular context of developmental immaturity under diminished responsibility, Ministry of Justice Consultation Paper (2008), n 21 above, 17.

83 Law Commission Report (2006), n 5 above. Furthermore, the Commission puts this second to the sentence mitigation principle (discussion of which is beyond the scope of this paper), since: 'when the offender has killed with the fault element for first degree murder but pleads a "partial defence" successfully, he or she still ought to be convicted of an offence of "murder" (second degree murder)', at [2.149].

84 That is, 'the ability to explain oneself, to give an intelligible account of oneself, to answer for oneself, as a rational being. In short it is exactly what it sounds like: responseability, an ability to respond', Gardner, n 69 above, 161.

85 Gardner, n 69 above, 157. Gardner borrows the term from Dworkin; R. Dworkin, SovereignVirtue: the Theory and Practice of Equality (Cambridge, Mass: Harvard University Press, 2000) at 287.

86 For criticism of Gardner's assertions see, N. Naffine, 'Moral Uncertainties of Rape and Murder: Problems at the Core of Criminal Law Theory' in B. McSherry et al (eds), Regulating Deviance: The Redirection of Criminalisation and the Futures of Criminal Law (Oxford and Portland Oregon: Hart Publishing, 2009) 213.

87 Gardner, n 69 above, 161. 
reduced by reason of their inability to account for their conduct, or rather by virtue of the fact that their mental disorder has meant that they should avoid (in part) the consequence of their wrongdoing?

The weight being afforded to the term 'recognised medical condition' under section 52 is representative of a marked shift towards the medicalisation of this area of law. Of course there is support for such a move particularly from the psychiatric community, ${ }^{88}$ but this deepening of the amalgamation of disciplines is curious when we consider the time-honoured argument that, because the principles of law and psychiatry are based on opposing paradigms, they cannot work together. Both claim to have a monopoly on understanding human behaviour but, paradoxically, appear to approach it from two different standpoints. ${ }^{89}$ Retaining the legal term 'diminished responsibility' in respect of a new law that has the effect of narrowing the defence to exclude anything that cannot be squeezed into a classification of a 'recognised medical condition' is not only unfair in terms of labelling, it does not do any favours for the Government's goal of attaining clarity either.

Inextricably linked with notions of fairness and clarity is the overarching principle of effectiveness. Effectiveness, or being adequate to realise the purpose for which a particular rule is implemented, goes to the heart of what the criminal law is trying to achieve. In terms of the purpose of diminished responsibility, the Law Commission pointed to a single, prominent and endless refrain' from the responses to its Consultation Paper in 2003, to the effect that: 'the partial defences of provocation and diminished responsibility have as their origin and main purpose the protection of the defendant from the mandatory death/life sentence for murder. ${ }^{, 90}$ It adds that ' $\mathrm{t}$ ] he huge discrepancy in sentence for a person who succeeds, or fails, in those defences has generated pressures to expand those defences. ${ }^{91}$ Noteworthy, then, is the fact that section 52 has the potential to narrow the defence of diminished responsibility for certain groups of offenders, as discussed above.

Another disappointment in terms of fairness is the failure of the new law to address the existing statutory sentencing framework for murder on the grounds that it is not directly relevant to governmental proposals and is outside the scope of the review. ${ }^{92}$ It was argued that removing the mandatory life sentence would allow mitigating features of homicide cases to be dealt with more easily without resorting to 'gateways' through which a defendant can escape a murder conviction in deserving but not undeserving cases. ${ }^{93}$ However, the Government's response to

88 The Royal College of Psychiatrists supported this change, saying of the new definition: 'Overall the effect would be to encourage better standards of expert evidence and improved understanding between the courts and experts.' Law Commission Report (2006) at [5.114].

89 For discussion, see J. Hunter and J. Bargen,'Diminished Responsiblity: "Abnormal” Minds, Abnormal Murderers and What the Doctor Said' in S. M. H. Yeo (ed), Partial Excuses to Murder (Sydney: The Federation Press, 1991); A. Kenny, Freewill and Responsibility (London: Routledge \& Kegan Paul, 1978); See S. T. Yannoulidis, 'Negotiating “Dangerousness” : Charting a Course Between Psychiatry and Law' (2002) 9 Psychiatry, Psychology and Law 151; M. S. Morse, Law and Psychiatry Rethinking the Relationship (Cambridge University Press 1984).

90 Law Commission Report (2004), n 5 above at [2.59].

91 ibid.

92 Ministry of Justice, Summary of Responses and Government Position, (2009) n 25 above at [118].

93 ibid. 
this point was that the penalty for murder is an essential element in maintaining public confidence in the criminal justice system and therefore something which the Government wishes to maintain. ${ }^{94}$ Clearly, this area is in need of further consideration in the context of the reform of diminished responsibility, as many of the issues relating to the construction of the partial defences could potentially be dealt with effectively by giving more discretion in sentencing to the judge in those cases where a partial defence is unsuccessful.

An examination of sentence mitigation is beyond the scope of this paper, suffice it to say that most commentators would suggest that the very existence of the doctrine of diminished responsibility is dependent upon the retention of the fixed penalty for murder, and that if the fixed penalty was abolished, diminished responsibility could be dispensed with. However, further consideration is unlikely to be given to the abolition of the mandatory life sentence in light of the fact that the Government started its review of the law of murder by reinforcing and redefining the remit of the partial defences.

\section{CONCLUDING REMARKS}

This paper identifies obscure phraseology and a lack of grounding in medical diagnosis as the primary criticisms pertaining to the original definition of diminished responsibility under section 2(1) of the Homicide Act 1957. It has considered how the new definition as set out under section 52 of the Coroners and Justice Act 2009 has responded to such criticisms, while bearing in mind the Government's propounded values of 'clarity, fairness and effectiveness'.

Section 52 goes some way towards clarifying the law of diminished responsibility. Most significantly, it defines what amounts to 'mental responsibility' and provides a medical basis for diagnoses under the section, with the introduction of the 'recognised medical condition' criterion. However, unforeseen consequences may lead to unfairness for certain categories of defendant, in light of the narrowing effect of the refined definition.

Fairness on a broader scale has also been considered. Deeper issues which go to the heart of the defence itself both in practice (procedural fairness) and in theory (fair labelling) need further consideration. It is unfortunate that the opportunity was not taken at this time to reassess the concept and application of diminished responsibility as a defence to murder from first principles, something which fell beyond the remit even of the Law Commission.

From a structural perspective, this paper identifies the segmented means of updating both the law of homicide and the law as it relates to offenders with a mental disorder. Section 52 is adrift in an Act dedicated to a conglomeration of issues, and suffers for it. It is regrettable that the opportunity to review the law in this area in its entirety was not availed of, particularly as reformulation of the original definition, although required, is not critical at this time.

94 ibid at [121]. 